\title{
Biofilm Formation by Salmonella Enteritidis at Different Incubation Temperatures
}

\author{
Laura Beatriz Rodrigues', Bruna Webber', Rafael Levandowski', Sara Souza Gehlen², \\ Luciana Ruschel dos Santos', Fernando Pilotto', Eduardo Cesar Tondo ${ }^{3}$ \& Vladimir Pinheiro do Nascimento ${ }^{2}$
}

\begin{abstract}
Background: The genus Salmonella, associated with poultry products, is considered the leading cause of foodborne outbreaks in humans in many countries. In Brazil, Salmonella Enteritidis (SE) is the serovar remains as one most frequently isolated from humans, and it is also a major serovar found in animals, food, animal feed, and environmental samples, despite all the efforts to control this pathogen. Also, the bacterium is able to form biofilms on different surfaces, protecting cells from both cleaning and sanitizing procedures in the food industries. This study aimed to verify the ability of Salmonella Enteritidis isolates to form biofilm on polystyrene at different incubation temperatures.

Materials, Methods \& Results: A total of 171 SE samples were isolated from foodborne outbreaks (foods and stool cultures) and poultry products between 2003 and 2010. The biofilm-forming ability of samples was measured at four different temperatures $\left(3^{\circ} \mathrm{C}, 9^{\circ} \mathrm{C}, 25^{\circ} \mathrm{C}\right.$, and $\left.36^{\circ} \mathrm{C}\right)$, for $24 \mathrm{~h}$, simulating temperatures usually found in poultry slaughterhouses. Later, $200 \mu \mathrm{L}$ of each bacterial suspension was inoculated, in triplicate, onto 96 -well, flat-bottomed sterile polystyrene microtiter plates, washed, after that, the biofilm was fixed with methanol. The plates were dried at ambient temperature, stained with 2\% Hucker's crystal violet. Afterwards, absorbance was read using an ELISA plate reader and the optical density (OD) of each isolate was obtained by the arithmetic mean of the absorbance of three wells and this value was compared with the mean absorbance of negative controls (ODnc). The following classification was used for the determination of biofilm formation: no biofilm production, weak biofilm production, moderate biofilm production and strong biofilm production. Results demonstrated all isolates from stool cultures and foods involved in foodborne outbreaks, at least one of the four temperatures tested, were able to form biofilm, even at $3^{\circ} \mathrm{C}$, undescribed as possible for the growth of SE. SE strains from poultry products also formed biofilm at least at one of the temperatures.

Discussion: The prevention of biofilms formation is very important, once they can be difficult to remove from utensils and food equipment surfaces, becoming a chronic source of microbial contamination of foods, possible dissemination of diseases, and increase of resistance to cleaning and sanitization procedures. A high ability for biofilm formation on plastic surfaces was observed. We may consider that Salmonella has the capacity to bind to surfaces, with relevant impacts on public health. Although biofilm formation could be affected by temperature, most of the SE isolates analyzed in our study were strong biofilm producers at all temperatures, including at $3^{\circ} \mathrm{C}$, a temperature used for food preservation and until then not acknowledged as worrisome regarding the development of Salmonella spp. There is a common sense that maintenance of food at low temperatures, particularly below $5^{\circ} \mathrm{C}$, is safer to consumers as low temperatures reduce microbial multiplication. However, our results show that the growth of SE in its sessile form is possible under refrigeration. These findings lead to the assumption that the ability of SE to form biofilms, especially at low temperatures, is related to its endurance in inhospitable environments, eventually infecting humans, and that may be one of the factors associated with the high prevalence of this serovar in outbreaks of foodborne diseases. To our knowledge, this is the first publication about biofilm formation by Salmonella Enteritidis at $3^{\circ} \mathrm{C}$.
\end{abstract}

Keywords: Salmonella Enteritidis, biofilm, incubation temperatures, foodborne outbreaks, poultry products.

DOI: $10.22456 / 1679-9216.89414$ 


\section{INTRODUCTION}

Salmonellosis is one of the most common foodborne diseases and millions of human cases are reported worldwide every year, resulting in thousands of deaths [38]. In most countries, foods containing meat and eggs are the leading causes of human enteritis outbreaks involving Salmonella $[3,14,22,36]$.

Salmonella Enteritidis (SE) is one of the most prevalent serotypes from human and non-human sources in the Americas, according to data from the Global Foodborne Infections Network (GFN) Country Databank $[6,38,39]$. Although many Salmonella serovars have been isolated, SE has been identified as the cause of the most cases of foodborne salmonellosis investigated in the state of Rio Grande do Sul in recent years $[15,20]$.

Most microorganisms in their natural habitats are attached to solid surfaces [10], indicating the great advantage of growth of microorganisms on biofilms $[4,5,7,8,32]$. Biofilm formation by Salmonella on surfaces in contact with food has been recognized as a contributing factor for foodborne outbreaks. Surfaces employed in food processing wear out after repeated use and are more likely to accumulate debris and bacteria $[16,25,29,33]$.

According to Lianou and Koutsoumanis [18], environmental parameters such as osmolarity, $\mathrm{pH}$, composition of the growth medium and incubation temperature [19] are able to affect the ability of biofilm formation. Therefore, the main objective of our study was to evaluate SE biofilm formation at different temperatures usually found in food industries.

\section{MATERIALS AND METHODS}

\section{Sampling and collection}

A total of $171 \mathrm{SE}$ samples, isolated between 2003 and 2010 in the state of Rio Grande do Sul, Southern Brazil, were analyzed. Eighty samples were isolated from stool cultures or foods involved in foodborne outbreaks and 90 from poultry products (chicken cuts, poultry organs, and drag swabs) and from a standard SE strain (ATCC 13076).

Stock culture samples were stored in Brain Heart Infusion broth (BHI) ${ }^{1}$, supplemented with $20 \%$ glycerol and maintained at $-20^{\circ} \mathrm{C}$. The tested microorganisms were reactivated in $\mathrm{BHI}$ broth, inoculated into xylose lysine deoxycholate agar (XLD) ${ }^{1}$, and their purity was confirmed by biochemical and serological tests. Working cultures were maintained on Tryptic Soy Agar slants (TSA) ${ }^{1}$ until analysis.

The samples were incubated under different environmental conditions at $3^{\circ} \mathrm{C}, 9^{\circ} \mathrm{C}, 25^{\circ} \mathrm{C}$, and $36^{\circ} \mathrm{C}$, in high-performance incubators (BOD Incubator, Tecnal TE-371 $)^{2}$, with the purpose of simulating the temperatures recommended for poultry slaughterhouses: $3 \pm 1^{\circ} \mathrm{C}$ (cooling temperature, maximum of $4^{\circ} \mathrm{C}$ ); 9 $\pm 1^{\circ} \mathrm{C}$ (cutting room temperature in slaughterhouses that export to the $\mathrm{EU}$, maximum of $\left.10^{\circ} \mathrm{C}\right) ; 25 \pm 1^{\circ} \mathrm{C}$ (ambient temperature); $36 \pm 1^{\circ} \mathrm{C}$ (standard for mesophilic growth).

Using a microprocessor-based digital temperature controller (precision of $\pm 0.3^{\circ} \mathrm{C}$ and uniformity of $\pm 0.3^{\circ} \mathrm{C}$ ), and were monitored during incubation by digital temperature monitoring devices (Digital Thermo Hygrometer Internal Temperature and $\mathrm{Hu}-$ midity) $)^{3}$.

\section{Biofilm formation}

The biofilm-forming ability of the isolates was measured by the technique described by Rodrigues et al. [28]. Therefore, a loopful of working cultures was transferred to TSB without dextrose (Tryptic Soy Broth without Dextrose) $)^{1}$, for incubation at $36 \pm 1{ }^{\circ} \mathrm{C}$ for $24 \mathrm{~h}$. Aliquots of the cultures were then added to inoculated TSB without dextrose until a $1 \mathrm{McF}$ arland standard was obtained (Nefelobac) $)^{4}$. Later, $200 \mu \mathrm{L}$ of each bacterial suspension was inoculated, in triplicate, onto 96-well, flat-bottomed sterile polystyrene microtiter plates ${ }^{5}$. Inoculated TSB wells, in a triplicate, were used as negative controls. The same procedures were repeated on three independent plates, which were incubated at four different temperatures $\left(3^{\circ} \mathrm{C}, 9^{\circ} \mathrm{C}, 25^{\circ} \mathrm{C}\right.$, and $36^{\circ} \mathrm{C}$ ) for $24 \mathrm{~h}$.

The bacterial suspension was aspirated and each well was washed three times with $250 \mu \mathrm{L}$ of sterile physiological saline $(0.9 \%)$. After that, the biofilm was fixed with $200 \mu \mathrm{L}$ of methanol6 for $15 \mathrm{~min}$ and later removed. The plates were dried at ambient temperature, stained with $200 \mu \mathrm{L}$ of $2 \%$ Hucker's crystal violet ${ }^{6}$ for $5 \mathrm{~min}$, washed in running water, and dried at ambient temperature. Afterwards, absorbance was read using an ELISA plate reader (Rosys Anthos 2010) ${ }^{7}$ at 550 $\mathrm{nm}[28]$. 
The optical density (OD) of each strain was obtained by the arithmetic mean of the absorbance of three wells and this value was compared with the mean absorbance of negative controls (ODnc). The following classification was used for the determination of biofilm formation: no biofilm production $(\mathrm{OD} \leq \mathrm{ODnc})$, weak biofilm production (ODnc $<$ ODs $\leq 2$.ODnc), moderate biofilm production (2.ODnc $<$ ODs $\leq 4$.ODnc), and strong biofilm production (4.ODnc $<$ ODs) [33-35].

\section{RESULTS}

All isolates were able to form biofilm, at least at one of the four temperatures tested, even at $3^{\circ} \mathrm{C}$, undescribed as possible for the growth of SE (Table 1). SE from foodborne outbreaks formed more biofilm than those of poultry origin unrelated to outbreaks, among which $4.4 \%$ of the isolates were strong biofilm producers and only $6.6 \%$ did not produce biofilms, while $52.8 \%$ of the isolates obtained from poultry products did not produce biofilms.

Table 1. Biofilm formation at $3^{\circ} \mathrm{C}, 9^{\circ} \mathrm{C}, 25^{\circ} \mathrm{C}$ and $36^{\circ} \mathrm{C}$ by Salmonella Enteritidis from foodborne outbreaks and poultry products.

\begin{tabular}{|c|c|c|c|c|c|c|c|c|}
\hline & \multicolumn{2}{|c|}{ No biofilm Production } & \multicolumn{2}{|c|}{ Weak biofilm production } & \multicolumn{2}{|c|}{ Moderate biofilm Production } & \multicolumn{2}{|c|}{ Strong biofilm production } \\
\hline & Outbreaks & Poultry & Outbreaks & Poultry & Outbreaks & Poultry & Outbreaks & Poultry \\
\hline $36^{\circ} \mathrm{C}$ & $8 / 80$ & $44 / 90$ & $30 / 80$ & $42 / 90$ & $37 / 80$ & $2 / 90$ & $5 / 80$ & $2 / 90$ \\
\hline $25^{\circ} \mathrm{C}$ & $7 / 80$ & $48 / 90$ & $41 / 80$ & $35 / 90$ & $27 / 80$ & $4 / 90$ & $5 / 80$ & $3 / 90$ \\
\hline $9^{\circ} \mathrm{C}$ & $8 / 80$ & $48 / 90$ & $62 / 80$ & $35 / 90$ & $8 / 80$ & $5 / 90$ & $2 / 80$ & $2 / 90$ \\
\hline $3^{\circ} \mathrm{C}$ & $8 / 80$ & $50 / 90$ & $60 / 80$ & $34 / 90$ & $8 / 80$ & $3 / 90$ & $4 / 80$ & $3 / 90$ \\
\hline$\%$ & $9.7 \%$ & $52.8 \%$ & $60.3 \%$ & $40.6 \%$ & $25.0 \%$ & $3.9 \%$ & $5.0 \%$ & $2.7 \%$ \\
\hline
\end{tabular}

\section{DISCUSSION}

Biofilms were initially quantified using a tube culture method with subsequent staining for their detection and recognition and the wells of the microtiter plates were then used as a vessel for culturing the microorganism and results were measured by spectrophotometry. Different methods can be used, such as test tubes, microtiter plates, microscopy, Congo red agar plates, biofilm formation on surfaces, cell enumeration, microscopy, among others but the microtiter plating technique remains as one of the methods most widely used in biofilm research [13,15,26,32,35,37].

Bacterial adhesion is a dynamic and complex process, regulated by several characteristics of the growth medium, of the substrate, and of the cell surface $[11,17]$ and it may be divided into primary and secondary stages. The first stage is reversible while the secondary one is not, and may occur in food processing environments $[10,11,32]$.

With respect to food safety, biofilms are important as they form on food, cooking utensils, and surfaces, and as they are difficult to remove. Their formation in industries is especially important because of their potential as a chronic source of microbial contamination of foods, dissemination of diseases, and increases in the resistance to cleaning and sanitization $[16,32,33]$.
The optimal growth temperature for Salmonella is $37^{\circ} \mathrm{C}$ [14], but growth may occur between $5^{\circ} \mathrm{C}$ and $45^{\circ} \mathrm{C}$. Although biofilm formation could be affected by temperature [18,27], most of the SE samples analyzed in our study were strong biofilm producers at all temperatures, including at $3^{\circ} \mathrm{C}$, temperature used for food preservation and until then not acknowledged as worrisome regarding the development of Salmonella spp. According to the Brazilian Directive 210 [2], carcasses and poultry products should be immediately cooled between $0^{\circ} \mathrm{C}$ and $4^{\circ} \mathrm{C}$. Therefore, the temperature of the last pre-cooling stage cannot be higher than $4^{\circ} \mathrm{C}$. Given the maximum variation of $1^{\circ} \mathrm{C}$, allowed during incubation, the temperature used in this study was $3^{\circ} \mathrm{C}$.

Studies that evaluated biofilm formation by Salmonella spp. and Listeria monocytogenes, found that these bacteria have a high capacity to form biofilm on plastic surfaces [33]. Other studies evaluated biofilm formation on polystyrene by Salmonella Heidelberg isolated from chicken carcasses and cloacal swabs, grown in TSB without dextrose supplemented with 0.5 to $4 \%$ glucose, and incubated at $36^{\circ} \mathrm{C}$ [28]. Most of the tested Salmonella Heidelberg strains were weak or no biofilm producers under different supplementations and only two isolates were strong biofilm producers when grown in TSB without dextrose. 
Microtiter assays with Salmonella spp. incubated at $37^{\circ} \mathrm{C}$ also found different results for biofilm production [12,30,31]. A high ability for biofilm formation on plastic surfaces was observed. We may consider that Salmonella has the capacity to bind to surfaces, with relevant impacts on public health.

Bacteria can adhere to surfaces and form biofilms [8,21], for the benefit of the bacterial population, such as multicellular organisms, being possible to became highly resistant to stressful environments [1]. It has been well documented that the genus Salmonella can not grow at temperatures between 4 and $8^{\circ} \mathrm{C}$ and that lower temperatures can reduce its presence [24]. The growth of $S$. Typhimurium and $S$. Heidelberg at $4^{\circ} \mathrm{C}, 7^{\circ} \mathrm{C}$, and $10^{\circ} \mathrm{C}$ in $\mathrm{BHI}$ and non-sterile chicken slurry and suggested that low temperatures are important factors for the survival and growth of both serovars [24]. These findings lead to the assumption that the ability of SE to form biofilms, especially at low temperatures, is related to its endurance in inhospitable environments, eventually infecting humans, and that may be one of the factors associated with the high prevalence of this serovar in outbreaks of foodborne diseases.

There is a common sense that maintenance of food at low temperatures, particularly below $5^{\circ} \mathrm{C}$, is safer to consumers as low temperatures reduce microbial multiplication. However, our results show that the growth of SE in its sessile form is possible under refrigeration.
Biofilm formation can be considered a selective advantage that facilitates bacterial persistence on surfaces [23]. Both cold storage and thermal treatment might alter the physicochemical properties of SE and lead to adhesion [40]. We demonstrated the possibility of biofilm formation on polystyrene, a plastic polymer that can be used for food preservation at different temperatures.

\section{CONCLUSION}

The relevance of this manuscript is the fact that the analyzed SE, especially those involved with foodborne outbreaks, formed biofilms at refrigeration temperatures, enhancing the chances of contamination of humans through consumption of foods stored refrigerated. To our knowledge, this is the first publication about biofilm formation by SE at this temperature.

\section{MANUFACTURERS}

${ }^{1}$ Difco Laboratories. Sparks, MD, USA.

${ }^{2}$ Tecnal Equipment for Laboratories. Piracicaba, SP, Brazil.

${ }^{3}$ Incoterm Soluções em Medição. Porto Alegre, RS, Brazil.

${ }^{4}$ Probac Brasil Produtos Bacteriológicos Ltda. São Paulo, SP, Brazil. ${ }^{5}$ Cral Laboratory Articles Ltda. Cotia, SP, Brazil.

${ }^{6}$ Vetec Fine Chemistry Ltda. Duque de Caxias, RJ, Brazil.

${ }^{7}$ Anthos Labtec Instruments. Salzburg, Austria.

Acknowledgments. The authors wish to thank FAPERGS (protocol 09/0351-2) for the financial support of this study.

Declaration of interest. The authors report no conflicts of interest. The authors alone are responsible for the content and writing of the paper.

\section{REFERENCES}

1 Barnhart M.M. \& Chapman M.R. 2006. Curli biogenesis and function. Annual Review of Microbiology. 60: 131-147.

2 Brazil. 1998. Portaria ${ }^{\circ} 210$, de 10 de novembro de 1998. Regulamento Técnico da Inspeção Tecnológica e HigiênicoSanitária de Carne de Aves. Brasília: Ministério da Agricultura, Pecuária e Abastecimento, 46p.

3 Cardoso A.L.S.P., Tessari E.N.C., Castro A.G.M. \& Kanashiro A.M.I. 2000. Pesquisa de Salmonella spp., coliformes totais, coliformes fecais e mesófilos em carcaças e produtos derivados de frango. Arquivos do Instituto Biológico. 67: 25-30.

4 Carpentier B. \& Cerf O. 1993. Biofilms and their consequences with particular reference to hygiene in the food industry. Journal of Applied Microbiology. 75: 99-511.

5 Carpentier B. 1997. Sanitary quality of meat chopping board surfaces: a bibliographical study. Food Microbiology. 14: 31-37.

6 Costalunga S. \& Tondo E.C. 2002. Salmonellosis in Rio Grande do Sul, 1997 to 1999. Brazilian Journal of Microbiology. 33: 342-346.

7 Costerton J.W., Cheng K.J., Geesey G.G., Ladd T.I., Nickel J.C., Dasgupta M. \& Marrie T.J. 1987. Bacterial biofilms in nature and disease. Annual Review of Microbiology. 41: 435-464.

8 Costerton J.W., Cheng K.J. \& Geesey G.G. 1995. Bacterial biofilms in nature and disease. Annual Review of Microbiology. 49: 711-745. 
9 Davey M.E. \& O’Toole G.A. 2000. Microbial biofilms: from ecology to molecular genetics. Microbiology and Molecular Biology Reviews. 64: 847-867.

10 Donlan R.M. \& Costerton J.M. 2002. Biofilms: Survival mechanisms of clinically relevant microorganisms. Clinical Microbiology Reviews. (15): 167-193.

11 Donlan R.M. 2002. Biofilms: microbial life on surfaces. Emerging Infectious Diseases. 8: 881-890.

12 Ebrahimi A., Hemati M., Dehkordi S.H., Bahadoran S., Khoshnood S., Khubani S., Faraj M. D. \& Alni R.H. 2014. Chlorhexidine digluconate effects on planktonic growth and biofilm formation in some field isolates of animal bacterial pathogens. Jundishapur Journal of Natural Pharmaceutical Products. 9: 14298.

13 Galinari E., Nóbrega J.E., Andrade N.J. \& Ferreira C.L.L.F. 2014. Microbiological aspects of the biofilm on wooden utensils used to make a Brazilian artisanal cheese. Brazilian Journal of Microbiology. 45: 713-720.

14 Gast R.K. 2008. Salmonella infections - Paratyphoid Infections. In: Saif Y.M., Fadly A.M., Glisson J.R., McDougald L.R., Nolan L.K., Swayne D.A. (Eds). Diseases of poultry. 12th edn. Ames: Blackwell Publishing Professional, pp.465516.

15 Geimba M.P., Tondo E.C., Oliveira F.A., Canal C.W. \& Brandelli A. 2004. Serological characterization and prevalence of spvR genes in Salmonella sp. isolated from foods involved in foodborne outbreaks occurred in Rio Grande do Sul, south of Brazil. Journal of Food Protection. 67: 1229-1233.

16 Jessens B. \& Lammert L. 2003. Biofilm and disinfection in meat processing plants. International Biodeterioration and Biodegradation. 51: 265-269.

17 Kumar G.C. \& Anand S.K. 1998. Significance of microbial biofilm in food industry: a review. International Journal of Food Microbiology. 42: 9-27.

18 Lianou A. \& Koutsoumanis K.P. 2012. Strain variability of the biofilm-forming ability of Salmonella enterica under various environmental conditions. International Journal of Food Microbiology. 160: 171-178.

19 Lima E.D.S.C.D., Pinto P.S.D.A., Santos J.L.D., Vanetti M.C.D., Bevilacqua P.D., Almeida L.P.D., Pinto M.S. \& Dias F.S. 2004. Isolation of Salmonella and Staphylococcus aureus at swine slaughtering as subsidy for HACCP, the hazard analysis and critical control point system. Pesquisa Veterinária Brasileira. 24: 185-190.

20 Malheiros P.S., Paula C.M.D. \& Tondo E.C. 2007. Cinética de crescimento de Salmonella Enteritidis envolvida em surtos alimentares no RS: uma comparação com linhagens de outros sorovares. Ciência e Tecnologia de Alimentos. 27: 751-755.

21 Marinho A.R., Martins P.D., Ditmer E.M., d'Azevedo P.A., Frazzon J., Van Der Sand S.T. \& Frazzon A.P.G. 2013. Biofilm formation on polystyrene under different temperatures by antibiotic resistant Enterococcus faecalis and Enterococcus faecium isolated from food. Brazilian Journal of Microbiology. 44: 423-426.

22 Mead G.C. 1989. Hygienic problems and control of process contamination. In: Mead G.C. (Ed). Processing of poultry. New York: Elsevier, pp.360-368.

23 Melo P.C., Ferreira L.M., Nader A.F., Zafalon L.F., Vicente H.I.G. \& Souza V. 2013. Comparison of methods for the detection of biofilm formation by Staphylococcus aureus isolated from bovine subclinical mastitis. Brazilian Journal of Microbiology. 44: 119-124.

24 Morey A. \& Singh M. 2012. Low-temperature survival of Salmonella spp. in a model food system with natural microflora. Foodborne Pathogens and Disease. 9: 218-223.

25 Parizzi S.Q.F., Andrade N.J., Silva C.A.S. \& Soares N.D.F.F. 2004. Bacterial adherence to different inert surfaces evaluated by epifluorescence microscopy and plate count method. Brazilian Archives of Biology and Technology. 47: 77-83.

26 Pitts B., Hamilton M.A., Zelver N. \& Stewart P.S. 2003. A microtiter-plate screening method for biofilm disinfection and removal. Journal of Microbiological Methods. 54: 269-276.

27 Rode T.M., Langsrud S., Holck A. \& Moretro T. 2007. Different patterns of biofilm formation in Staphylococcus aureus under food-related stress conditions. International Journal of Food Microbiology. 116: 372-383.

28 Rodrigues L.B., Santos L.R.D., Rizzo N.N., Tagliari V.Z., Oliveira A.P.D., Trenhago G., Rodegheri S.C., Taglitti R.M., Dickel E.L. \& Nascimento V.P.D. 2009. Avaliação da hidrofobicidade e da formação de biofilme em poliestireno por Salmonella Heidelberg isoladas de abatedouro avícola. Acta Scientiae Veterinariae. 37: 225-230.

29 Rodrigues L.B., Santos L.R.D., Rizzo N.N., Tagliari V.Z., Trenhago G., Oliveira A.P., Ferreira D., Pilotto F. \& Nascimento V.P.D. 2013. Salmonella and Listeria from stainless steel, polyurethane and polyethylene surfaces in the cutting room of a poultry slaughterhouse. Acta Scientiae Veterinariae. 41: 1164. 
30 Seixas R., Gabriel M., Machado J., Tavares L., Bernardo F. \& Oliveira M. 2014. Effect of simulated gastrointestinal conditions on biofilm formation by Salmonella 1,4,[5],12:i:-. Scientific World Journal. ID (153956): 5.

31 Seixas R., Machado J., Bernardo F., Vilela C. \& Oliveira M. 2014. Biofilm formation by Salmonella enterica serovar 1,4,[5],12:i:- Portuguese isolates: a phenotypic, genotypic, and sociogeographic analysis. Current Microbiology. 68: 670-677.

32 Steenackers H., Hermans K., Vanderleyden J. \& Keersmaecker S.C.J. 2012. Salmonella biofilms: An overview on occurrence, structure, regulation and eradication. Food Research International. 45: 502-531.

33 Stepanovic S., Irkovic I.C., Ranin L. \& Svabic-Vlahovic M. 2004. Biofilm formation by Salmonella spp. and Listeria monocytogenes on plastic surface. Letters in Applied Microbiology. 38: 428-432.

34 Stepanovic S., Vukovic D., Dakic I., Savic B. \& Vlahovic M.S.A. 2000. Modified microtiter-plate test for quantification of staphylococcal biofilm formation. Journal of Microbiological Methods. 40: 175-179.

35 Stepanović S., Vuković D., Hola V., Bonaventura G.D., Djukić S., Ćirković I. \& Ruzicka F. 2007. Quantification of biofilm in microtiter plates: overview of testing conditions and practical recommendations for assessment of biofilm production by staphylococci. APMIS. 71: 687-690.

36 Wagner V.R., Silveira J.B. \& Tondo E.C. 2013. Salmonelloses in the State of Rio Grande do Sul, southern Brazil, 2002 to 2004. Brazilian Journal of Microbiology. 44: 723-729.

37 Wang H., Ding S., Wang G., Xu X. \& Zhou G. 2013. In situ characterization and analysis of Salmonella biofilm formation under meat processing environments using a combined microscopic and spectroscopic approach. International Journal of Food Microbiology. 167: 293-302.

38 WHO. 2017. World Health Organization. Health Topics: Salmonella. Disponível em: <http://www.who.int/foodsafety/ areas_work/foodborne-diseases/salmonella/en/>. [Accessed online in November 2017].

39 WHO. 2013. World Health Organization. Global Network Global Foodborne Infections Network. Global Salm Surv. Disponível em: <http://thor.dfvf.dk/pls/portal/GSS.COUNTRY_DATA_SET_REP.show_parms>[Accessed online in April 2016].

40 Yang Y., Kumar A., Zheng Q. \& Yuk H.G. 2015. Preacclimation alters Salmonella Enteritidis surface properties and its initial attachment to food contact surfaces. Colloids and Surfaces B: Biointerfaces. 128: 577-585. 